\title{
Models and Mapping Tools to Inform \\ Resilience Planning After Disasters: A Case Study of Hurricane Sandy and Long Island Ecosystem Services
}

\author{
Mark Myer and John M. Johnston
}

\begin{abstract}
In the aftermath of Superstorm Sandy in 2012, recovery and rebuilding efforts focused on resilience and diversified infrastructure that included consideration of the benefits that healthy ecosystems provide. County governments on Long Island identified a need for tools to map coastal and estuarine areas that may provide ecosystem services. Current methods of ecosystem service mapping often rely on complicated statistical models, labor-intensive site validation, or proprietary data. We examined a method of fast ecosystem services mapping that relies on publiclyavailable data, includes stakeholder input, and uses ArcGIS software that is ubiquitous in municipal planning. This chapter provides an example of ecosystem service mapping that generates easily explained visualizations suitable for non-scientific audiences with tools already available to municipal planning departments. We explain how to define indicators of benefit presence, obtain data, and create maps using examples from a collaboration with Nassau County, Long Island, New York.
\end{abstract}

\section{Lessons Learned}

- Some situations do not require an effort-intensive modeling approach to ecosystem services mapping - for these, a quick estimate serves the purpose.

- Consulting with stakeholders at every step of the process is essential. As researchers, our ideas of which ecosystems and benefits are important may not match theirs.

- It is possible to map the areas that may provide ecosystem services using publicly available data with a combination of expert consultation and inductive reasoning.

M. Myer

City of New Orleans Mosquito Termite and Rodent Control Board, New Orleans, LA, USA

J. M. Johnston $(\bowtie)$

US EPA Office Research and Development, Center for Environmental Measurement and

Modeling, Athens, GA, USA

e-mail: johnston.johnm@epa.gov

(C) The Author(s) 2020 


\section{Needs to Advance EBM}

- Despite several contemporaneous efforts, there is no agreed-upon standard to rigorously define ecosystem services. This subjectivity introduces uncertainty into service mapping.

- Local partners may not immediately perceive utility in ecosystem-based management, underscoring the need for communication and outreach that enumerates its advantages over established paradigms.

\section{Hurricane Sandy and the South Shore of Nassau County}

Superstorm Sandy made landfall in New Jersey and New York on October 29, 2012, leaving behind a wake of destruction along the U.S. eastern seaboard. The storm caused billions of dollars in damage, killed at least 147 people in the United States (Blake et al. 2013) and dozens more overseas, and it left millions temporarily without electricity and fuel (Diakakis et al. 2015). In Nassau County, Long Island, New York, voluntary evacuations were announced for the south shore's storm surge area in anticipation of extensive damage. On impact, Sandy's storm surge was nearly $14 \mathrm{ft}$ above mean low tide, causing inundation of coastal areas and shoreline changes from erosion and accretion of sand and sediment (Hapke et al. 2013). Disruption to south shore bays from an influx of salt water and sediment was widespread, including a reduction in eelgrass (Zostera marina), which serves as a crucial habitat for local shellfish (Tinoco 2017). In the aftermath of the storm, New York City and the surrounding communities committed to rebuilding and adding infrastructure in ways that increased resilience to future natural disasters, with consideration of green infrastructure methods of reducing stormflow, increasing infiltration, and reducing nutrient runoff to improve ecosystem services (Interboro Team 2014; The City of New York 2013). As part of the Federal response to the disaster, the U.S. Environmental Protection Agency's Office of Research and Development and Region 2 (including New York, New Jersey and Puerto Rico) worked with the Federal Emergency Management Agency, New York Department of State, county policy makers, and others to identify projects that diversify the built and green infrastructure portfolio while increasing community resilience to natural disasters.

Hempstead Bay is in the western part of Long Island's south shore embayment, extending approximately from Far Rockaway in Queens to Massapequa in southeastern Nassau County (Fig. 1). Long Beach forms the barrier between the Bay and the Atlantic Ocean on the cityward side, with Jones Beach continuing the chain of barrier islands to the east. The area supports a diversity of ecosystems, including freshwater streams, brackish streams, tidal wetlands and marshes, seagrass and open bay, and barrier islands. The Bay is integral to the lifestyle enjoyed by residents, both by providing ecosystem services directly and indirectly supporting others. Shellfishing for clams, oysters, and scallops is both a recreational activity and part of the local economy, with bay scallops alone contributing millions of dollars per year (Peconic Estuary Program 2015). Sailing and recreational boating are enjoyed 


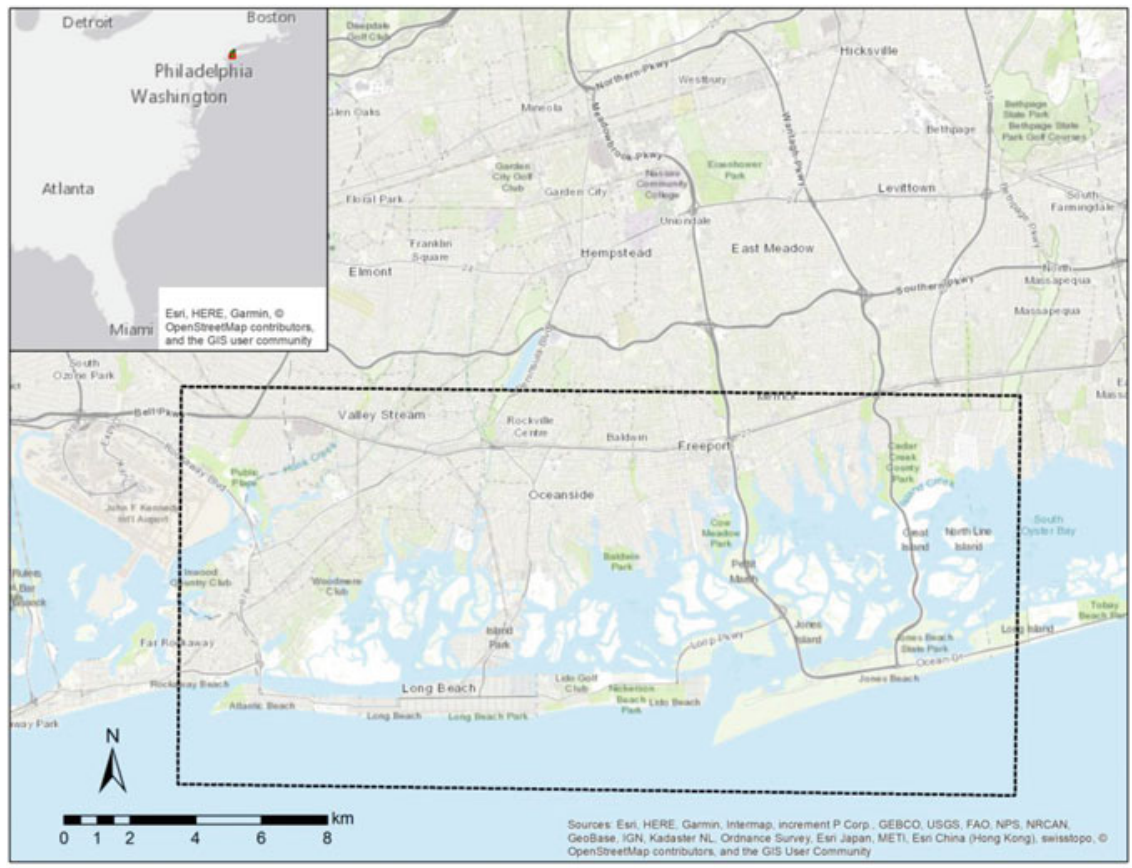

Fig. 1 Study Area: South shore of Nassau County in Long Island, NY. Hempstead Bay is located between the south shore and Long Beach, in the dotted box

in the warmer seasons. Several rare and endangered birds including the piping plover (Charadrius melodus) and yellow-crowned night heron (Nyctanassa violacea) reside in the area, which makes it a destination for birdwatchers (Cohen et al. 2006; Hodgman et al. 2015). Aquatic vegetation, both emergent and submerged, attenuates wave energy and decreases inundation from storm surge (Paul et al. 2012). The Bay ecosystem is recovering but faces pressures from development and pollution. The south shore experienced decades of stressors from development activities resulting in loss of submerged aquatic vegetation and coastal wetlands and increased nutrient loadings that impair coastal ecosystems (Hartig et al. 2002). Local commercial shellfish landings are far from historic highs because of habitat loss. Though storms are a normal dynamic of coastal ecosystems, areas stressed by human activity have less resilience, limiting their ability to recover from disturbance (Carpenter et al. 2001). The maps and methods described here were provided to the county planning office to help communicate the presence of and potential for enhancement of ecosystem services. Increasing awareness of local ecosystems and their services, especially through the use of intuitive maps, was a first step in building understanding of the relationships between wetland vegetation and coastal resilience and fisheries production. 


\section{Background on Nature's Benefits}

We consider the term "nature's benefits"- the benefits of nature that people care about - to be synonymous with ecosystem services. Final ecosystem goods and services are provided or created by ecosystems and directly enjoyed or utilized by people. We acknowledge the distinction between final and intermediate services (Lamothe and Sutherland 2018; DeWitt et al. 2020); however, we don't address this further. Our goal was to help Nassau County visualize and communicate the location of benefits that people derive from the Bay, therefore we used the informal, intuitive concept of nature's benefits. We avoid confusing the concept by clarifying that any part of the Bay that is utilized or enjoyed and was not built by people is a nature's benefit.

The local government of Nassau County (Fig. 1) managers were interested in mapping nature's benefits to identify priority areas of the Bay that provide multiple services and to determine what benefits are located near areas of planned development. They wanted to identify, characterize, and describe locations that provide nature's benefits as part of public communication and outreach tools as part of overall efforts to mitigate negative impacts from human activity and to target efforts that support those benefits.

\section{Geographic Information Systems-Utility of Arc ModelBuilder}

The desired product for Nassau County was an illustrative map, suitable for inclusion in a handout or a poster for public-facing communication, that could be quickly produced without a long, data-gathering process. Inspired by the "service-providing area" maps of Angradi et al. (2016) used to visually characterize geographical areas that provide targeted ecosystem services, these are intended to quickly convey where benefits are likely to occur. Although they are simplifications of the natural world, a major strength is that they may not require fieldwork or an expensive monitoring program to generate. Nature's benefit maps outline the geographical areas that have the potential to provide ecosystem services, conveying those benefits through the use of a few, easily described indicators that outline the boundaries/presence of a given benefit. We considered cost, simplicity, and end-user ease-of-use as drivers of the overall design goals, and we targeted county and municipal planners (and their communications staff) as the intended users.

To meet these design goals, we used the ModelBuilder semi-automated map-building feature available in ESRI ArcGIS, the most popular and widely used Geographic Information System (GIS). GIS is used to work with spatial data and create maps and is considered an essential tool in municipal planning, environmental science, ecology, environmental economics, and many other disciplines. ModelBuilder is a visual representation of GIS operations in ArcGIS as a directed 


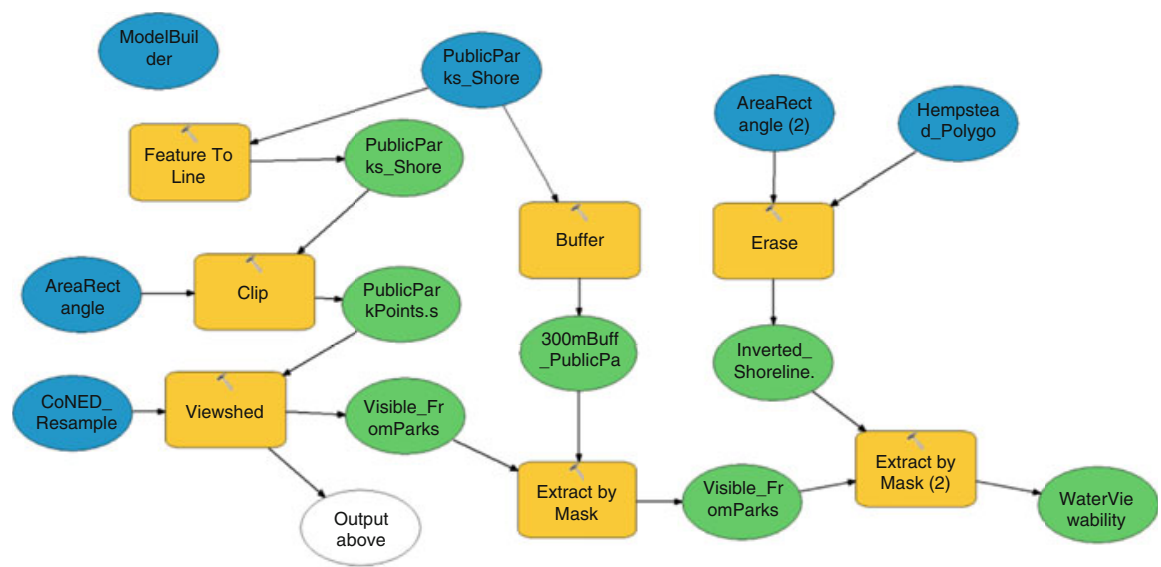

Fig. 2 A ModelBuilder directed graph (i.e., a GIS workflow) used to create a map of areas of the shore suitable for recreational viewing of aquatic animals. A blue oval is a map file, a yellow box is a GIS operation, and a green or clear oval is an output file

graph (Fig. 2). Shapes and colors are used to represent a map file, a table of input data, a mapping operation, or an output file. Following the arrows shows the GIS workflow as steps from input to output. For example, in Fig. 2, the input file PublicParks_Shore is a shapefile that contains areas of public parkland adjacent to the ocean and is represented as a blue oval. Following the two arrows from the PublicParks_Shore input, the map operations performed on the shapefile are Feature To Line, which turns the shape into a line, and Buffer, which outputs a polygon of the area a given distance from its input. Map operations are represented as orange rectangles. The output is represented as a green oval that can be used in other map operations, creating a continuous workflow. A ModelBuilder workflow can be saved as a portable file and shared for reuse and editing by other users with ArcGIS software. Benefits maps can be delivered with ModelBuilder files as a compressed archive with all required input data in a single package.

\section{Steps to Generate a Nature's Benefits Map}

Generating a nature's benefit map begins with local knowledge to determine which benefits are present and amenable to mapping. It is important to consult with residents, representatives of businesses that are associated with the local landscape (farming, fishing, or ecotourism for example), political representatives, and researchers including ecologists, hydrologists, and geologists. Consulting as many experts as possible strengthens the impact of the product and fosters inclusion and ownership. Soliciting the values and preferences of the various stakeholders also helps rank the priority order of the potential list of benefits (Sharpe et al. 2020). Meetings, surveys, or personal correspondence can all be used to determine which 
benefits are most important to a community. It may be necessary to brainstorm a preliminary list of benefits to jumpstart conversations, especially among audiences that have not been exposed to ecosystem services concepts. It is also possible to highlight the benefits of nature that may be overlooked or underappreciated by including these in a preliminary list for stakeholder consultation.

Amenability to benefits mapping means that a particular benefit should be present in a fixed location and there should be information available to determine indicators of its presence. Reliable indicator data must be available to determine the location of benefits so that GIS operations can be performed to identify their location across the county (i.e., area of interest). Benefits must occur in a discrete location that can be visualized on a map to be considered amenable. If a benefit rarely exists or occurs almost everywhere, it is unlikely to be a good choice for nature's benefits mapping as it may not help inform differences between management alternatives for a particular decision. For example, reduction of bay nitrogen pollution is a benefit related to the presence of denitrifying bacteria (Christensen et al. 1987). However, microscopic bacteria can potentially occur everywhere in the Bay, and their location and abundance are also in flux, so it is difficult or impossible to map this benefit.

\section{Indicator Selection}

Because many benefits cannot be directly observed or quantified, we use indicators to estimate their presence. In our case indicators are environmental (i.e., habitat) characteristics known to occur with the presence of a plant or animal species. We define an indicator as a mappable (fixed, measurable) quantity that spatially co-occurs with the benefit. As such, nature's benefits maps indicate where a benefit may be present but is not guaranteed. In other words, the presence of the indicator is necessary but not sufficient to ensure the presence of the benefit. Reliable indicators are crucial because a map based on faulty assumptions will be misleading or incorrect. The guiding question to ask is "what are the one or two characteristics that are almost always present when this benefit is provided?"

To illustrate indicator selection, we use the examples of hard clam gathering and shore fishing. For the hard clam example, the benefit is those clams that are harvestable, so metrics are needed to convert this benefit into rules for mapping the extent of this benefit. Because clam collectors can only reach so far underwater, even if they are using a specialized tool, one indicator will be water depth less than $2 \mathrm{~m}$ (about $6 \mathrm{ft}$ ) at mean tide, which will represent the area where a collector could reasonably reach the bottom of the Bay at low tide (Wells 1957). The second indicator represents areas where hard clams are likely to live. We researched the ecology of the hard clam and found they tend to live in areas with a sand or mud bottom (Wells 1957; Walker and Tenore 1984). Therefore, our indicators for hard clam collecting are areas of the Bay with a sand or mud bottom in two meters or less depth at mean tide, because that is where hard clams that people can reach are most likely to occur. It's important to note that only clams that people can harvest are 
considered a nature's benefit: if they can't be collected, they aren't considered a benefit. Because of this, most nature's benefit maps include at least one accessibility indicator.

Similarly, for shore-based fishing, indicators should reflect the potential of the public to catch fish while standing on a shore. The first indicator will be those areas identified as shoreline; the area must be adjacent to water, because an angler needs to be on the shore to catch fish. Our second indicator for shore-based fishing is public accessibility, for example state or local parks. Finally, an angler can reasonably cast a line about $30 \mathrm{~m}$ (around $90 \mathrm{ft}$ ) at the most, so benefits locations will be within $30 \mathrm{~m}$ of shoreline. Combining these indicators results in areas that provide the benefit of shore-based fishing.

\section{Mapping Indicators}

Once indicators that provide the mapping boundaries of a given nature's benefit are chosen, the next step is to find spatial data to represent the indicator, download it preferably from a publicly available source, and load it into a GIS platform. Indicators can be in almost any geodata format, from elevation and land cover rasters to wetland and soil type polygons and bathymetry contours. In the eight examples created for Nassau County, publicly available indicator data were used, avoiding the need for the use of proprietary or privileged information.

In the example of hard clam gathering, our first indicator was an indicator of accessibility, as water depth two meters or less at mean tide. A raster elevation map showing water depth of tidal zones is the indicator, and we used the Coastal National Elevation Database Project (United States Geological Survey 2019). The website contains a download link for the Topobathymetric Digital Elevation Model (https:// gis.ny.gov/elevation/NYC-topobathymetric-DEM.htm), which shows the data availability for coastal U.S. waters. As an example of ensuring that indicator data are current and not outdated, we used a special report on the website that detailed how the topography and bathymetry model was adjusted after Hurricane Sandy (Stronko 2013). The second indicator was sand bottom type. Bay bottom substrate type was provided by the United States Fish and Wildlife Service's National Wetlands Inventory (NWI) (United States Fish and Wildlife Service 2019). This dataset includes wetland and estuarine ecosystems for the coastal United States. We obtained the Wetlands and Deepwater Code Diagram from the NWI to provide the bottom substrate of estuaries and bays (Fig. 3).

For shore-based fishing, obtaining all of the indicators was more challenging. For the first indicator, an internet search for "United States shoreline polygons" directed us to the National Oceanic and Atmospheric Administration's (NOAA) Office for Coastal Management shoreline website (National Oceanic and Atmospheric Administration 2019) where we ultimately chose the NOAA Composite Shoreline dataset, which the site says is for high-resolution cartographic work. We then clipped it to our study area using GIS to reflect the south Hempstead Bay area. 


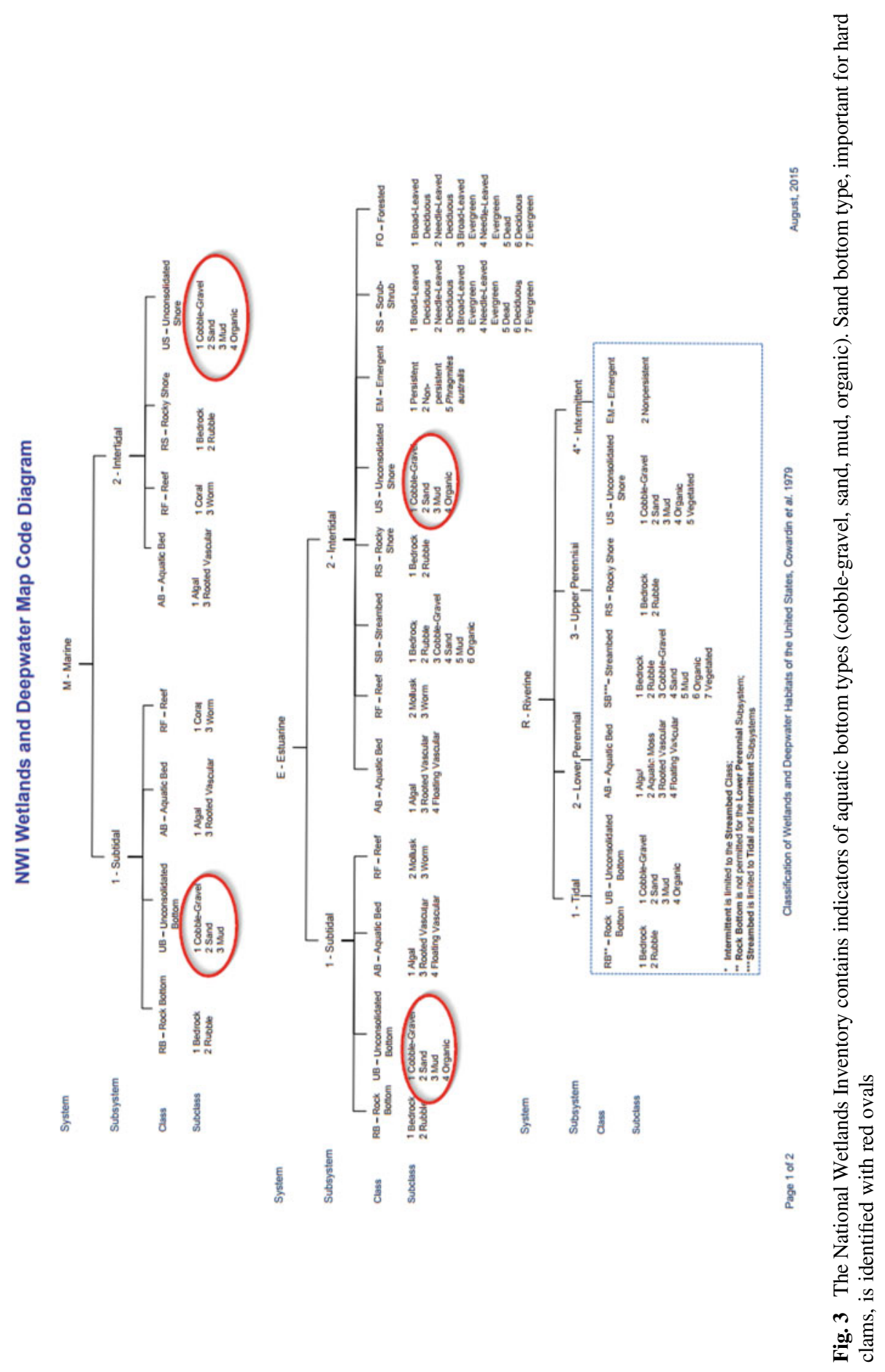




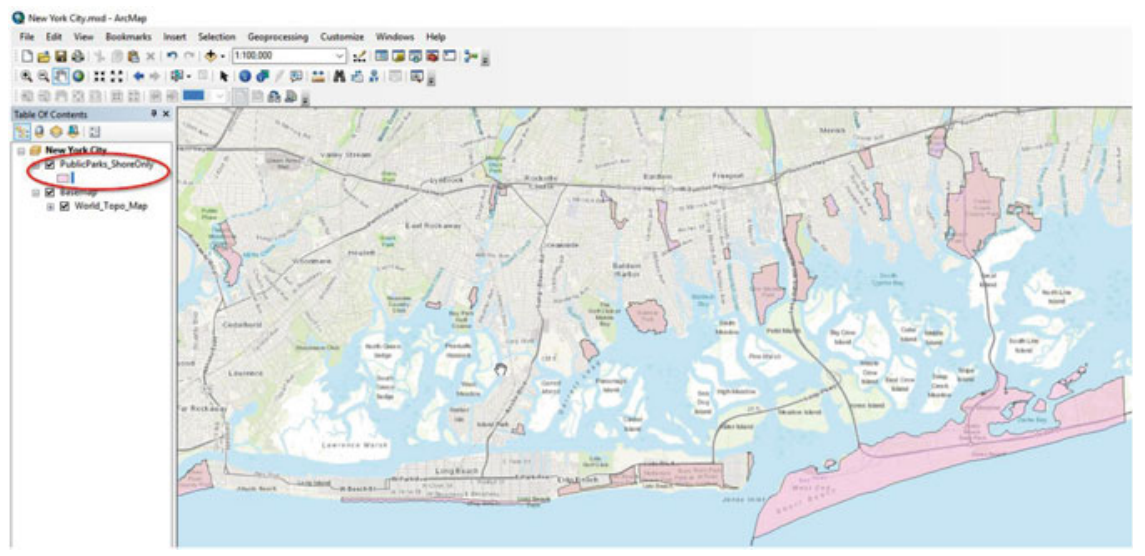

Fig. 4 Screen capture of ArcMap's Table of Contents for Nassau County shoreline fishing benefits mapping. Public parks indicator was created from other data

The second indicator, publicly-accessible areas, didn't exist for our area of interest, therefore, we created it. The ESRI World Topographic Map is provided with an ArcGIS Online subscription, and we traced the boundaries of all the areas labeled as public parks or beaches along the shore using the Editor tool to create a new polygon file (Fig. 4). Unlike other indicator data, these were not from a U.S. government source. Even though we did not use the original map, instead we referred to it as a guide to make a new polygon file, it is important to examine the type of license to ensure proper use and to credit the original source on any documents as demonstrated in Figs. 5(a and b).

The third indicator for shore-based fishing was any area of publicly-accessible shoreline within $30 \mathrm{~m}$ of shore. We used distance buffering within ArcGIS ModelBuilder to include only areas within $30 \mathrm{~m}$, and there was no need to download another indicator dataset.

\section{Nature's Benefits in Nassau County}

Our collaboration with Nassau County started with an initial list of 20 nature's benefits. Soliciting input from the anticipated end users of the maps was essential in delivering a useful product. Some of our initial choices of benefits, such as SCUBA diving and guided boat touring, were ruled out as requiring excessively subjective judgments to choose indicators. Others, like waterfowl hunting and seal habitat, were discarded because they were deemed less important. After two rounds of deliberation, we chose the following benefits: bay scallop habitat, hard clam collecting, shore fishing, offshore striped bass fishing, summer flounder fishing, vegetative wave attenuation, aquatic animal viewscapes, and yellow-crowned night heron habitat. 


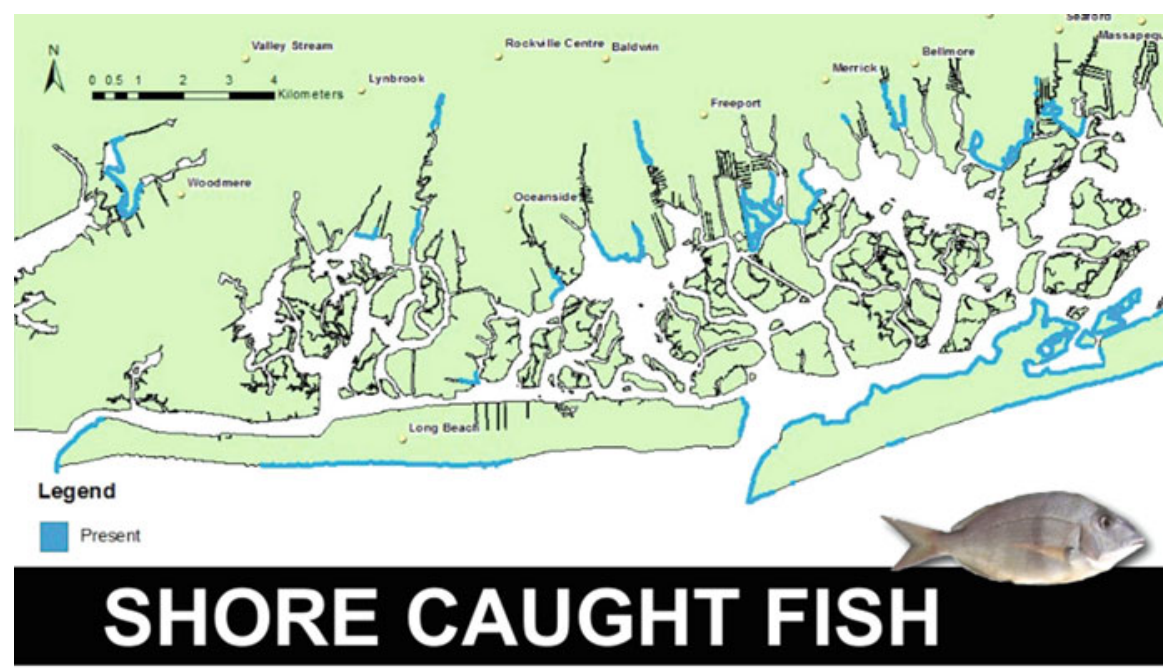

Line fishing from the shore, by a single angler. Private property is not included in this service, and areas shown represent areas that are accessible from public land.

\section{Ecosystem Service Type}

\begin{tabular}{|l|}
\hline Present \\
\hline Absent \\
\hline Rationale \\
\hline
\end{tabular}

Cultural and Provisioning (a non-material benefit that contributes to the development and cultural advancement of people, and a product obtained from an ecosystem).
Liiting Factor

Data Sources

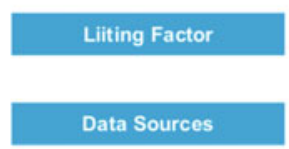

For Further Reading

Areas of shoreline that are within 30 meters of a publicly-accessible park, beach, or recreational area.

Areas of shoreline that are greater than 30 meters from a publicly-accessible park, beach, or recreational area.

The service of shore-caught fish is present within 30 meters of publicly-accessible shore points, which represents the maximum distance that an angler could reasonably cast a line.

Accessibility of shoreline to anglers. Areas of the shore that are privately owned were not included as public resources.

Locations of publicly-accessible parks, beaches, and recreational areas: Author's polygon drawing based on Google Maps and ESRI World Topographical Map. Shoreline: National Oceanic and Atmospheric Administration (NOAA) Office for Coastal Management Composite Shoreline

List of public access to New York and Long Island marine waters for beach fishing and boat launches with contact information:

hitp://www dec.ny. gov/outdoor/7901. htm

Fig. 5 (a and b) Nature's Benefits handouts for shore fishing and hard clam collecting

This stakeholder collaboration effort resulted in eight nature's benefit maps that illustrated a variety of benefits important to people who live on the Bay. We created 1-page handouts for each nature's benefit map (e.g., Figs. 5(a and b)), explained the indicators used to create it, and provided background information on the benefit along with further reading. Data sources were included with the example handouts, and a selection of the peer-reviewed literature that guided our choice of indicators 


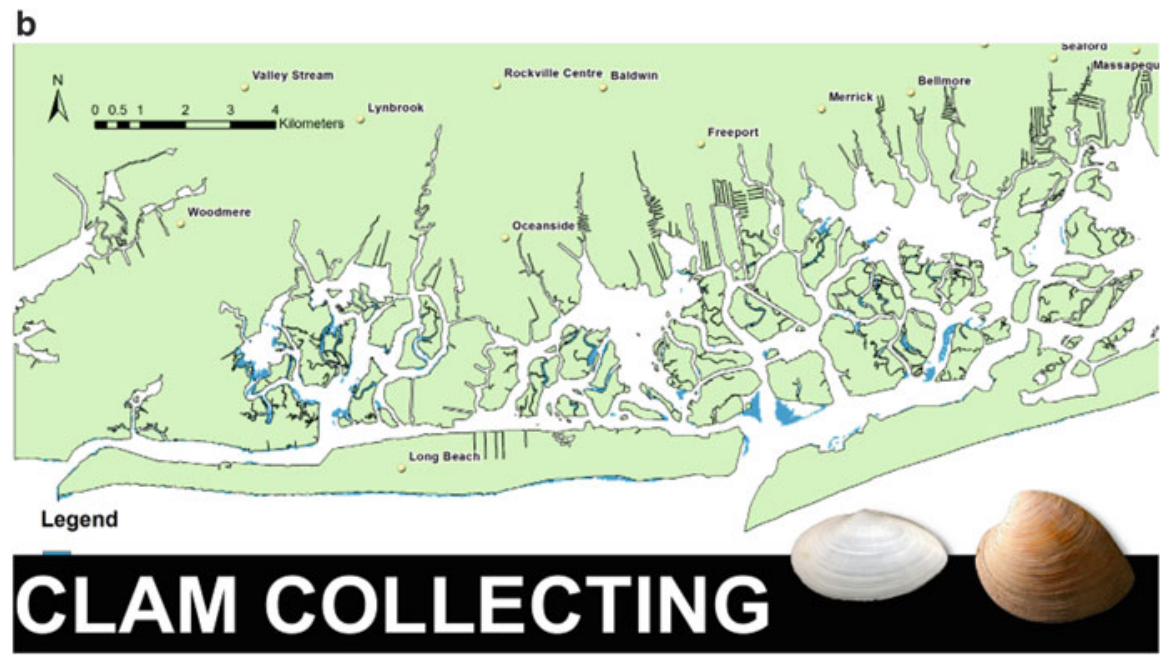

Non-commercial collecting of hard shell (Mercenaria mercenaria) or soft shell (Mya arenaria) clams from shallow intertidal marine waters, either on foot or in a small boat.

Ecosystem Service Type Provisioning (a product obtained from an ecosystem).

\begin{tabular}{|c|c|}
\hline Present & $\begin{array}{l}\text { Areas in the intertidal zone with a sand or mud bottom type that are less than } \\
2.0 \text { meters deep. }\end{array}$ \\
\hline Absent & $\begin{array}{l}\text { Areas that are not in the intertidal zone, have bottom types other than sand and } \\
\text { mud, and/or are greater than } 2.0 \text { meters deep. }\end{array}$ \\
\hline Rationale & $\begin{array}{l}\text { Clamming is conducted on foot or in a canoe/kayak and requires the ability to reach } \\
\text { the bottom. Clams prefer sand or mud substrates in the intertidal zone. }\end{array}$ \\
\hline Limiting Factor & $\begin{array}{l}\text { Areas with a sand or mud bottom type near the shore. Many of the near-shore areas } \\
\text { that are shallow enough for damming have a rocky or unconsolidated bottom that } \\
\text { makes clam collecting difficult. }\end{array}$ \\
\hline Data Sources & $\begin{array}{l}\text { Bathymetry: USGS Coastal National Elevation Database (CoNED) } 2014 \\
\text { Bottom type and aquatic vegetation: USFWS National Wetland Inventory (NWI) } \\
\text { Shoreline: National Oceanic and Atmospheric Administration (NOAA) Office for Coastal } \\
\text { Management Composite Shoreline }\end{array}$ \\
\hline
\end{tabular}

For Further Reading University of Michigan Animal DiversityWeb on hard clam habitat http:/lanimaldiversity.org/accounts/Mercenaria_mercenaria/.

Fig. 5 (continued)

was listed in a "For Further Reading" section. We provided a comprehensive package to Nassau County that included the eight benefit handouts, all input files, Arc ModelBuilder files, a Further Reading document that included peer-reviewed literature supporting indicator choices, and two guidance documents. A summary was also provided with an illustrated step-by-step manual that guides a user through 
indicator election, creating new maps, and navigating the GIS software for making changes to the Nature's benefit maps.

\section{Synthesis-Using Nature's Benefit Maps}

The utility of nature's benefit maps is in their intuitive ease-of-use and their clarity of presentation. They are especially effective for communicating benefits to a non-scientific audience, including decision makers in local governments involved with planning and zoning where consideration of nature's benefits may reach a more sustainable and resilient solution. In our collaboration with the New York Department of State and Nassau County Department of Public Works, two use cases were prominent: (1) from a regional perspective, identifying areas of nature's benefit hotspots (i.e., multiple overlapping benefits); and (2) from an implementation or management perspective, identifying the most limiting factor determining the spatial extent of the benefit. Ecosystems, such as coastal emergent wetlands, that provide a high density of benefits can be managed for preservation or actively improved. For vegetative wave attenuation the limiting factor was the extent of emergent aquatic vegetation, rather than submerged aquatic vegetation or the extent of wetland, intertidal, and aquatic zones. Knowing the limiting factor allows planners to communicate how best to increase the amount of a nature's benefit, possibly increasing its spatial extent. Decision makers and the public both wanted to know where benefits were located and how to manage to potentially increase benefits. Nature's benefits mapping provides both information needs for decision support.

A moderate degree of skill with GIS is required. A user needs to know how to arrange files in the proper directories for ArcGIS, open and edit ModelBuilder, and must have some familiarity with GIS operations like clipping to be able to fully utilize the tool. ArcGIS is required to utilize ModelBuilder and replicate the examples here, but we decided this was acceptable because ArcGIS is in widespread use in municipal planning departments, such as the Nassau County government, who are the primary end-users. This approach is broadly transferable to other GIS platforms, including open-source software such as QGIS (https://qgis.org/en/site/). Maps are considered provisional, indicating the potential for benefits, unless fieldwork is done to confirm benefit presence and absence.

End-user guidance and feedback at each step (sometimes described as being "codeveloped") was invaluable in delivering products the county could use. The handouts served as templates for other benefits, and we recommend that nature's benefit maps be used in the initial stages of planning, including developing and evaluating potential alternative scenarios for a given management effort. These modeling and mapping tools have applications in health impact assessments, environmental impact assessments, and municipal planning and zoning. Our emphasis was on making best use of publicly available data and translating these clearly for ease-of-use, including end-user modification and extension to serve a range of interests and needs. 
Acknowledgements We would like to acknowledge the following individuals for their invaluable contributions to numerous project discussions, including Rabi Kieber (USEPA Region 2), Jonathan Halfon (FEMA), Elizabeth Codner-Smith (TNC), Anthony Dvarskas (Stony Brook), Paul Beyer (NYDOS), Muluken Muche and Florence Fulk (USEPA), Barry Pendergrass (NYDOS), Carolyn LaBarbiera (NYDOS), Sean Sallie and Joseph Cuomo (Nassau County Dept. of Public Works), Nadia Seeteram (ORISE) and Bennett Brooks (Consensus Building Institute). Although this document has been reviewed in accordance with Environmental Protection Agency (EPA) policy and approved for publication, it may not necessarily reflect official agency policy. Mention of trade names or commercial products does not constitute endorsement or recommendation for use. This research was supported in part by an appointment to the ORISE Fellowship Program at the U.S. EPA, Office of Research and Development, Athens, Georgia, administered by the Oak Ridge Institute for Science and Education through Interagency Agreement No. DW8992298301 between the U.S. Department of Energy and the U.S. EPA.

Disclaimer This chapter has been subjected to Agency review and has been approved for publication. The views expressed in this paper are those of the author(s) and do not necessarily reflect the views or policies of the U.S. Environmental Protection Agency.

\section{References}

Angradi, T. R., Launspach, J. J., Bolgrien, D. W., Bellinger, B. J., Starry, M. A., Hoffman, J. C., Trebitz, A. S., Sierszen, M. E., \& Hollenhorst, T. P. (2016). Mapping ecosystem service indicators in a Great Lakes estuarine area of concern. Journal of Great Lakes Research, 42 (3), 717-727.

Blake, E. S., Kimberlain, T. B., Berg, R. J., Cangialosi, J. P., \& Beven, J. L. I. (2013). Tropical cyclone report Hurricane Sandy (AL182012). National Hurricane Center.

Carpenter, S., Walker, B., Anderies, J. M., \& Abel, N. (2001). From metaphor to measurement: Resilience of what to what? Ecosystems, 4(8), 765-781.

Christensen, J. P., Murray, J. W., Devol, A. H., \& Codispoti, L. A. (1987). Denitrification in continental shelf sediments has major impact on the oceanic nitrogen budget. Global Biogeochemical Cycles, 1(2), 97-116.

Cohen, J. B., Fraser, J. D., \& Catlin, D. H. (2006). Survival and site fidelity of piping plovers on Long Island, New York. Journal of Field Ornithology, 77(4), 409-417.

DeWitt, T. H., Berry, W. J., Canfield, T. J., Fulford, R. S., Harwell, M. C., Hoffman, J. C., Johnston, J. M., Newcomer-Johnson, T. A., Ringold, P. L., Russel, M. J., Sharpe, L. A., \& Yee, S. J. H. (2020). The final ecosystem goods and services (FEGS) approach: A beneficiarycentric method to support ecosystem-based management. In T. O'Higgins, M. Lago, \& T. H. DeWitt (Eds.), Ecosystem-based management, ecosystem services and aquatic biodiversity: Theory, tools and applications (pp. 127-148). Amsterdam: Springer.

Diakakis, M., Deligiannakis, G., Katsetsiadou, K., \& Lekkas, E. (2015). Hurricane Sandy mortality in the Caribbean and continental North America. Disaster Prevention and Management: An International Journal, 24(1), 132-148.

Hapke, C., Brenner, O., Hehre, R., \& Reynolds, B. (2013). Coastal change from Hurricane Sandy and the 2012-13 winter storm season-Fire Island, New York. (Open-File Report 2013-1231). U.S. Geological Survey. Retrieved from http://pubs.usgs.gov/of/2013/1231/.

Hartig, E. K., Gornitz, V., Kolker, A., Mushacke, F., \& Fallon, D. (2002). Anthropogenic and climate-change impacts on salt marshes of Jamaica Bay, New York City. Wetlands, 22(1), 71-89.

Hodgman, T. P., Elphick, C. S., Olsen, B. J., Shriver, W. G., Correll, M. D., Field, C. R., Ruskin, K. J., \& Wiest, W. A. (2015). The conservation of tidal marsh birds: Guiding action at the 
intersection of our changing land and seascapes. Saltmarsh Habitat \& Avian Research Program.

Interboro Team. (2014). Living with the Bay: A comprehensive regional resiliency plan for Nassau County's South shore. Retrieved from https://www.hud.gov/sites/documents/INTERBORO_ IP_BRIEFING_BOOK.PDF.

Lamothe, K. A., \& Sutherland, I. J. (2018). Intermediate ecosystem services: The origin and meanings behind an unsettled concept. International Journal of Biodiversity Science, Ecosystem Services \& Management, 14(1), 179-187.

National Oceanic and Atmospheric Administration. (2019). NOAA Shoreline Website. Retrieved from https://shoreline.noaa.gov/.

Paul, M., Bouma, T. J., \& Amos, C. L. (2012). Wave attenuation by submerged vegetation: Combining the effect of organism traits and tidal current. Marine Ecology Progress Series 444:31-41

Peconic Estuary Program. (2015). Restoring the Peconic Bay Scallop. Retrieved from https://www. peconicestuary.org/peconic-bay-scallop/.

Sharpe, L., Hernandez, C., \& Jackson, C. (2020). Prioritizing stakeholders, beneficiaries and environmental attributes: A tool for ecosystem-based management. In T. O'Higgins, M. Lago, \& T. H. DeWitt (Eds.), Ecosystem-based management, ecosystem services and aquatic biodiversity: Theory, tools and applications (pp. 189-212). Amsterdam: Springer.

Stronko, J. (2013). Hurricane Sandy science plan-Coastal impact assessments: U.S. Geological Survey Fact Sheet 2013-3090. Retrieved from https://pubs.usgs.gov/fs/2013/3090/.

The City of New York. (2013). A stronger, more resilient New York. PlaNYC.

Tinoco, A. (2017). Effects of Hurricane Sandy on Great South Bay, Long Island: Assessing water quality, seagrass and associated nekton communities (M.S. Marine and Atmospheric Science). Brook, NY: Stony Brook University Stony.

United States Fish and Wildlife Service. (2019). National spatial data infrastructure-wetlands layer. Retrieved from https://www.fws.gov/wetlands/data/NSDI-Wetlands-Layer.html.

United States Geological Survey. (2019). USGS EROS Archive-Digital Elevation-Coastal National Elevation Database (CoNED) Project-Topobathymetric Digital Elevation Model (TBDEM). Retrieved from https://www.usgs.gov/centers/eros/science/usgs-eros-archive-digi tal-elevation-coastal-national-elevation-database-coned?qt-science_center_objects=0\#qt-sci ence_center_objects.

Walker, R., \& Tenore, K. (1984). The distribution and production of the hard clam, Mercenaria mercenaria, in Wassaw Sound, Georgia. Estuaries, 7(1), 19-27.

Wells, H. (1957). Abundance of the hard clam Mercenaria mercenaria in relation to environmental factors. Ecology, 38(1), 123-128. https://doi.org/10.2307/1932134.

Open Access This chapter is licensed under the terms of the Creative Commons Attribution 4.0 International License (http://creativecommons.org/licenses/by/4.0/), which permits use, sharing, adaptation, distribution and reproduction in any medium or format, as long as you give appropriate credit to the original author(s) and the source, provide a link to the Creative Commons licence and indicate if changes were made.

The images or other third party material in this chapter are included in the chapter's Creative Commons licence, unless indicated otherwise in a credit line to the material. If material is not included in the chapter's Creative Commons licence and your intended use is not permitted by statutory regulation or exceeds the permitted use, you will need to obtain permission directly from the copyright holder.

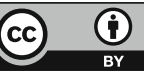

